\title{
Perancangan Sistem Pendukung Keputusan Pemberian Kredit Pemilikan Rumah (KPR) Dengan Metode Simple Additive Weighting
}

\author{
Tanto $^{1}$ \\ ${ }^{1}$ Program Studi Informasi, Fakultas Teknologi Informasi- Universitas Serang Raya \\ Jl. Raya Cilegon - Serang Km.5 Taman Drangong Kota serang - Banten, indonesia \\ ${ }^{1}$ tanto@gmail. com
}

\begin{abstract}
Kredit merupakan suatu fasilitas keuangan yang memungkinkan seseorang atau badan usaha untuk meminjam uang untuk membeli produk dan membayarnya kembali dalam jangka waktu yang ditentukan. PT.Bank Tabungan Negara (BTN) KCP Serang merupakan memiliki beberapa kegiatan perusahanan salah satunya adalah Kredit Pemilikan Rumah (KPR). Dalam proses pengajuan KPR, pihak Bank mengalami kesulitan menentukan calon nasabah yang berhak menerima KPR dan proses pengajuan KPR yang dilakukan oleh calon nasabah membutuhkan proses dan waktu yang cukup lama. Dari hal tersebut dibutuhkan suatu sistem pendukung keputusan pemberian KPR di Bank BTN KCP Serang.

Sistem pendukung keputusan adalah sistem yang dapat membantu seseorang dalam mengambil keputusan yang akurat dan tepat sasaran. Salah satu metode yang digunakan dalam SPK adalah simple additive weighting (SAW). SAW merupakan metode yang paling banyak digunakan dalam memecahkan permasalahan, seperti dalam SPK penentuan kelayakan nasabah penerima KPR. Metode SAW pemberian KPR memiliki beberapa kriteria yang menjadi dasar pengambilan keputusan antara lain character, capacity, capital, collateral dan condition. Hasil penelitian ini adalah membuat aplikasi sistem pendukung keputusan pemberian KPR untuk memberikan kemudahan dalam pengambilan keputusan pemberian KPR..
\end{abstract}

Kata kunci: Sistem, SPK, SAW, KPR.

\section{LATAR BELAKANG}

Pertumbuhan penduduk di Indonesia yang terjadi dari tahun ke tahun semakin meningkat jumlahnya, maka meningkat pula kebutuhan masyarakat atas penyediaan pelayanan. Meningkatnya jumlah penduduk, akan meningkatkan pula kebutuhan masyarakat akan tempat tinggal. Namun, tidak semua golongan masyarakat memiliki jumlah penghasilan yang cukup untuk memiliki atau mengontrak rumah. Dalam rangka memberikan kemudahan kepemilikan rumah, PT. Bank Tabungan Negara (BTN) memberikan kemudahan layanan yang lebih besar bagi para Konsumen untuk memiliki rumah, dengan dibukanya layanan Kredit Pemilikan Rumah (KPR).

Kredit Pemilikan Rumah (KPR) saat ini masih melalui mekanisme pengambilan keputusan pemberian kredit secara manual oleh analisis kredit. Hal ini menjadikan pengolahan data kredit dinilai tidak efisien dalam pertimbangan pemberian kredit pemilikan rumah dan waktu pengajuan kredit menjadi cukup lama (berdasarkan wawancara dengan nasabah), maka dirasa perlu untuk membangun sebuah sistem yang dapat membantu pihak Bank (tugas analisis kredit) dalam memberikan keputusan secara cepat dan tepat.

Sesuai dengan peraturan yang sudah ditentukan oleh pihak Bank untuk pemberian kredit, maka diperlukan kriteriakriteria untuk menentukan siapa yang berhak menerima kredit. Berdasarkan permasalahan yang ada, di perlukan sebuah sistem pendukung keputusan guna membantu penentuan nasabah yang layak menerima pemberian bantuan bank BTN. Salah satu metode yang dapat digunakan untuk sistem pendukung keputusan berkaitan dengan permasalahan tersebut diatas adalah dengan menggunakan metode Simple Additive Weighting (SAW). Metode Simple Additive Weighting (SAW) digunakan untuk mencari alternatif terbaik berdasarkan kriteria-kriteria yang telah ditetapkan oleh Bank.

Berdasarkan adanya permasalahan tersebut, maka pada penelitian ini akan menganalisa sistem pemberian kredit pemilikan rumah.

\section{DASAR TEORI}

\section{A. Sistem}

Menurut Jogiyanto (2009 : 683) menyatakan, Sistem adalah sebagai suatu kesatuan yang terdiri dari dua atau lebih komponen atau subsistem yang beriteraksi untuk mencapai suatu tujuan

\section{B. Sistem Pendukung keputusan}

Menurut Asep Abdul Wahid, Andri Ikhwana dan Partono (2012) menyatakan, sistem Pendukung Keputusan merupakan suatu sistem interaktif yang mendukung keputusan dalam proses pengambilan keputusan melalui alternatif-alternatif yang diperoleh dari hasil pengolahan data, informasi dan rancangan model.

\section{Simple Additive Weighting (SAW)}

Menurut Yulison Herry Chrisnanto, Faiza Renaldi dan Kiki Purwati (2012) menyatakan, Metode SAW sering juga dikenal sebagai metode penjumlahan terbobot. Konsep dasar metode SAW adalah mencari penjumlahan terbobot dari rating kinerja pada setiap alternatif pada semua atribut. Metode SAW membutuhkan proses normalisasi matriks keputusan (X) ke suatu skala yang dapat diperbandingkan dengan semua rating alternatif yang ada 


\section{Unified Modelling Language}

Menurut Haviluddin (2011) menyatakan, Unified Modelling Language merupakan alat perancangan sistem yang berorientasi pada objek. Secara filosofi kemunculan UML diilhami oleh konsep yang telah ada yaitu konsep permodelan Object Oriented (OO), karena konsep ini menganalogikan sistem seperti kehidupan nyata yang didominasi oleh obyek dan digambarkan atau dinotasikan dalam simbol-simbol yang cukup spesifik maka Object Oriented (OO) memiliki proses standard dan bersifat independen.

\section{ANALISIS DAN PERANCANGAN SISTEM}

a. Analisa SPK Penilaian Kelayakan KPR Menggunakan Metode SAW

Penentuan nasabah KPR pada PT.Bank Tabungan Negara KCP Serang, berdasarkan pada penilaian Credit Analyst, yaitu Character (kepribadian), Capital (uang muka), Capacity (kemampuan), Collateral (jaminan), dan Condition (kondisi). Dengan Kriteria yang telah ditentukan oleh pihak Bank diharapkan dengan menggunakan metode SAW dapat memperkuat keputusan yang diambil.

Pemberian bobot per kriteria

Langkah awal metode Simple Additive Weighting adalah pemberian nilai bobot di setiap kriteria pemohon KPR. Kelima tersebut dapat dibuat tabel sebagai berikut: Tabel 4.1 Pemberian Bobot Kriteria

\begin{tabular}{|l|l|l|}
\hline Kode & Nama Kriteria & Nilai Bobot \\
\hline C1 & Character (Kepribadian) & 25 \\
\hline C2 & Capital (Uang Muka) & 10 \\
\hline C3 & Capacity (Kemampuan) & 45 \\
\hline C4 & Collateral (Jaminan) & 10 \\
\hline C5 & Condition (Kondisi) & 10 \\
\hline
\end{tabular}

\section{b. Pemberian nilai pada tiap kriteria}

Dari kriteria di atas, dibuat suatu tingkatan sub kiteria berdasarkan alternatif yang telah ditentukan kedalam nilai. Tabel 4.2 nilai kriteria character

\begin{tabular}{|c|c|c|}
\hline Kriteria & Keterangan & Nilai \\
\hline \multirow{5}{*}{ 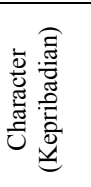 } & Sangat Kurang & 20 \\
\hline & Kurang & 30 \\
\hline & Cukup & 40 \\
\hline & Baik & 80 \\
\hline & Sangat Baik & 100 \\
\hline
\end{tabular}

Tabel 4.3 nilai kriteria capital

\begin{tabular}{|c|c|c|}
\hline Kriteria & Keterangan & Nilai \\
\hline \multirow{5}{*}{ 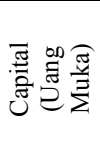 } & $\mathrm{DP}<15 \%$ dari harga & 20 \\
\hline & DP $16-20 \%$ dari harga & 30 \\
\hline & DP $21-25 \%$ dari harga & 40 \\
\hline & DP $26-30 \%$ dari harga & 80 \\
\hline & $\mathrm{DP}>30 \%$ dari harga & 100 \\
\hline
\end{tabular}

Berdasarkan kriteria setiap alternatif pada setiap kriteria yang telah ditentukan, selanjutnya penjabaran alternatif setiap kriteria yang telah dikonversikan dengan nilai, seperti tabel dibawah ini.

Tabel 4.8 kriteria penjabaran alternatif setiap kriteria

\begin{tabular}{|l|l|l|l|l|l|}
\hline \multirow{2}{*}{ Alternatif } & \multicolumn{5}{|c|}{ Kriteria } \\
\cline { 2 - 6 } & $\mathrm{C} 1$ & $\mathrm{C} 2$ & $\mathrm{C} 3$ & $\mathrm{C} 4$ & $\mathrm{C} 5$ \\
\hline Bachtiar & 20 & 100 & 20 & 75 & 20 \\
\hline Agus & 100 & 20 & 100 & 75 & 30 \\
\hline Deni & 40 & 30 & 40 & 100 & 100 \\
\hline
\end{tabular}

Ket :

$\mathrm{C} 1=$ Character, $\mathrm{C} 2=$ Capital, $\mathrm{C} 3=$ Capacity ,C4 = Collateral, $\mathrm{C} 5=$ Condition

Melakukan normalisasi matriks dengan cara menghitung nilai rating kinerja ternormalisasi (rij) dari alternatif.

$$
r_{i j=} \frac{x_{i j}}{\max x_{i j}}
$$

Perhitungan

$\mathrm{R} 11=\frac{20}{100}=0,2$

R $12=\frac{100}{100}=1$

$\mathrm{R} 13=\frac{20}{100}=0,2$

R $14=\frac{75}{100}=0,7$

R $15=\frac{20}{100}=0,2$

R $21=\frac{100}{100}=1$

R $22=\frac{20}{100}=0,2$

R $23=\frac{100}{100}=1$

R $24=\frac{75}{100}=0,7$

R $25=\frac{30}{100}=0,3$

R $31=\frac{40}{100}=0,4$

\begin{tabular}{|l|l|l|l|}
\hline \multirow{2}{*}{$\begin{array}{l}\text { krit } \\
\text { eria }\end{array}$} & \multicolumn{3}{|c|}{ Alternatif } \\
\cline { 2 - 4 } & Bachtiar & \multicolumn{1}{|c|}{ Agus } & \multicolumn{1}{|c|}{ Deni } \\
\hline C1 & Sangat kurang & Sangat baik & Cukup \\
\hline C2 & $\begin{array}{l}\text { DP }>30 \% \text { dari } \\
\text { harga }\end{array}$ & $\begin{array}{l}\text { DP }<15 \% \text { dari } \\
\text { harga }\end{array}$ & $\begin{array}{l}\text { DP 16-20\% } \\
\text { dari harga }\end{array}$ \\
\hline C3 & Sangat kurang & Sangat baik & Cukup \\
\hline C4 & $\begin{array}{l}\text { Rumah yang } \\
\text { akan } \\
\text { dikreditkan }\end{array}$ & $\begin{array}{l}\text { Rumah yang } \\
\text { akan } \\
\text { dikreditkan }\end{array}$ & $\begin{array}{l}\text { Sertifikat } \\
\text { tanah }\end{array}$ \\
\hline C5 & Sangat kurang & Kurang & Sangat baik \\
\hline
\end{tabular}

$\mathrm{R} 32=30 / 100=0,3$

$\mathrm{R} 33=40 / 100=0,4$

$\mathrm{R} 34=100 / 100=1$

$\mathrm{R} 35=100 / 100=1$

Dari perhitungan diatas diperoleh matriks ternormalisasi, sebagai berikut: 
$\mathrm{R}=\left[\begin{array}{ccccc}0,2 & 1 & 0,2 & 0,7 & 0,2 \\ 1 & 0,2 & 1 & 0,7 & 0,3 \\ 0,4 & 0,3 & 0,4 & 1 & 1\end{array}\right]$

\section{HASIL DAN PEMBAhasan}

Berdasarkan pemaparan dan pembahasan pada permasalahan, maka dapat dibuat kesimpulan sebagai berikut :

a. Perancangan sistem pendukung keputusan pemberian KPR telah memberikan alternative dan kemudahan bagi pihak bank dalam memberikan informasi kepada calon nasabah.

b. Perancangan sistem pendukung keputusan pemberian KPR dapat dirancang dengan menggunakan metode Simple Additive Weighting (SAW), hal ini dirasakan sangat efektif dan efisien, karena hasil dari keputusan sesuai dengan perhitungan bobot kriteria yang telah ditentukan oleh pihak bank, sehingga hasil keputusan lebih akurat. Selain itu perancangan sistem pendukung keputusan pemberian KPR telah memberikan kemudahan dalam proses pengambilan keputusan, sehingga dapat mempersingkat waktu.

\section{DAFTAR PUSTAKA}

[1] Chrisnanto Herry Yulison, Renaldi Faiza dan Purwati Kiki. (2012). "Sistem Pendukung Keputusan Berbasis WebDalam Memilih Produk telepon Genggam menggunakan Metode Simple Additive Weighting". Jurnal Teknologi Informasi dan Komunikasi. 1-45. ISBN :978-602-19837-0-6

[2] Jogiyanto. (2009). pengenalan komputer. Yogyakarta : Andi.Wahid Abdul Asep, Ikwana Andri dan Partono. (2012). "Sistem Pendukung Keputusan Penentuan Jumlah Pemesanan Barang". Jurnal Algoritma.Vol.9. 1-8. ISSN : 2302-7339 [2] Arianto (2012). "Sistem Pendukung Keputusan Pemilihan Karyawan Terbaik Dengan Metode SAW Studi Kasus Dipamela Swalayan”. Teknik Informatika (6) Hlm. 1-96.

[3] Kurnia Indah Citra, Tanuwijaya Haryanto dan Sagirani Tri. (2013). "Rancang Bangun Sistem Informasi Food Court Pada Pusat Pembelanjaan smart Surabaya". Jurnal Sistem Informasi. Vol. 2. No. (2). 8-13. ISSN :2338137X [6]

[4] Munandar Tb. Ai (2013). "Metode Penyelesian Masalah Pendukung Keputusan Menggunakan MADM". Sistem Informasi (26).

[5] Wiharti Wiwiet Yuri, Mustafidah Hindayanti dan Hamka Muhammad. (2012). "Analisa Hubungan Antara Penilaian Kompetisi Professional Dosen Oleh Mahasiswa Dan Kehadiran Mahasiswa Terhadap Nilai Kelulusan Mahasiswa Menggunakan Fuzzy Quantification Theory 1". Jurnal JUITA. Vol.2. No. (2). 100-112. ISSN :2086-9398 